\title{
Effects of hydrology, watershed size, and agricultural practices on sediment yields in two river basins in lowa and Mississippi
}

\author{
G.H. Merten, H.L. Welch, and M.D. Tomer
}

\begin{abstract}
The specific sediment yield (SSY) from watersheds is the result of the balance between natural, scale-dependent erosion and deposition processes, but can be greatly altered by human activities. In general, the SSY decreases along the course of a river as sediments are trapped in alluvial plains and other sinks. However, this relation between SSY and basin area can actually be an increasing one when there is a predominance of channel erosion relative to hillslope erosion. The US Geological Survey (USGS) conducted a study of suspended sediment in the Iowa River basin (IRB), Iowa, and the Yazoo River basin (YRB), Mississippi, from 2006 through 2008. Within each river basin, the SSY from four largely agricultural watersheds of various sizes (2.3 to $35,000 \mathrm{~km}^{2}$ [0.9 to $\left.\left.13,513 \mathrm{mi}^{2}\right]\right)$ was investigated. In the smallest watersheds, YRB sites had greater SSY compared to IRB sites due to higher rain erosivity, more erodible soils, more overland flow, and fluvial geomorphological differences. Watersheds in the YRB showed a steady decrease in SSY with increasing drainage basin area, whereas in the IRB, the maximum SSY occurred at the 30 to $500 \mathrm{~km}^{2}$ (11.6 to 193 $\mathrm{mi}^{2}$ ) scale. Subsurface tile drainage and limits to channel downcutting restrict the upstream migration of sediment sources in the IRB. Nevertheless, by comparing the SSY-basin size scaling relationships with estimated rates of field erosion under conservation and conventional tillage treatments reported in previous literature, we show evidence that the SSY-basin size relationship in both the IRB and YRB remain impacted by historical erosion rates that occurred prior to conservation efforts.
\end{abstract}

Key words: agriculture — annual sediment loads—scale effect—sediment yield—soil management practices

\begin{abstract}
Watershed disturbance by changes in land use, soil management practices, dam construction, and dredging and straightening of channels has resulted in substantial changes in the sediment loads of rivers around the world (Walling 2008). In the United States, changes in sediment load by watershed disturbance have resulted in hydrologic, ecologic, and engineering effects both upstream and downstream (Walling 1999; Horowitz 2010). Changes in land use from forest and prairie to agricultural land during the 19th century accelerated the erosion process, transferring sediment from uplands to valleys and the fluvial system (Trimble 1999). Later, during the 20th century, reservoir construction and soil conservation programs implemented in agricultural areas reduced sediment transference
\end{abstract}

sediment yield has contributed to a loss of coastal wetlands in Louisiana in excess of 90 $\mathrm{km}^{2} \mathrm{y}^{-1}\left(34.7 \mathrm{mi}^{2} \mathrm{yr}^{-1}\right)$, landward erosion rates

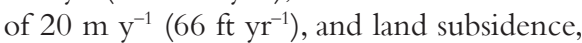
which could make the area more vulnerable to damage from hurricanes (Delaune et al. 1992; Horowitz 2010).

A better understanding of the effects of soil conservation practices at the watershed scale is still needed (Duriancik et al. 2008; Tomer and Locke 2011). There is an extensive body of literature describing plot- or field-scale conservation practices designed to protect water quality, water quantity, and soil quality. However, results from these studies often fail to capture the complexities and interaction of conservation practices, biophysical settings, and land uses within a watershed (Duriancik et al. 2008). The actual effect of conservation practices on soil erosion is extremely difficult to measure at the field and watershed scale due to the challenges of sampling and the diversity of sediment sources and sinks in fields and watersheds (Minella et al. 2014). According to the 2007 National Resource Inventory, soil erosion of cropland between 1982 and 2007 was reduced by about 30\% in the Corn Belt (Kansas, Illinois, Indiana, Iowa, Missouri, and Nebraska) and lower Mississippi River states (Arkansas, Louisiana, and Mississippi) as a result of soil conservation practices (USDA NRCS 2010). The major sources of sediment in streams are no longer fields and uplands, but rather fluvial channels (Renwick and Andereck 2006; Simon and Klimetz 2008; Renwick and Rakovan 2010).

Reductions in erosion seen at the plot and field scale are often not apparent at the macrobasin scale. This has raised doubt about the efficacy of conservation practices, undermining efforts to garner support for conservation agriculture (Dos Reis Castro et al. 1999; Leys et al. 2010). In fact, soil loss and sediment delivery measured at one spatial scale do not consistently correlate with what is Mississippi River. Nonetheless, Meade an Moody (2010) reported that the MissouriMississippi dams trap only about $1 \times 10^{8}$ to $1.5 \times 10^{8} \mathrm{Mg}\left(1.102 \times 10^{8}\right.$ to $1.653 \times 10^{8}$ tn) of sediment per year, which is less than half of the estimated $4 \times 10^{8} \mathrm{Mg}(4.409 \times$ $\left.10^{8} \mathrm{tn}\right)$ per year transported by the MissouriMississippi River system prior to 1900 . The remaining decrease in annual suspended sediment loads can be attributed to engineering activities, such as locks, bank revetments, and soil conservation practices. This decrease in
Gustavo H. Merten is an assistant professor in the Department of Civil Engineering at the University of Minnesota-Duluth, Minnesota. Heather L. Welch is a hydrologist for the US Geological Survey (USGS), Lower Mississippi-Gulf Water Science Center in Jackson, Mississippi. Mark D. Tomer is a research soil scientist for the USDA Agricultural Research Service, National Laboratory for Agriculture and the Environment in Ames, lowa. 
measured at other scales; linear additivity is not valid for sediment transport (Osterkamp and Toy 1997; de Vente and Poesen 2005; Leys et al. 2010). The relation between erosion from individual fields and sediment yield at the basin outlet is largely unknown (Walling 1983; van Noordwijk et al. 1998). Most eroded material never leaves the landscape to enter rivers (Minella et al. 2014). This is one of the reasons why soil erosion equations such as the Modified Universal Soil Loss Equation (MUSLE; Williams and Berndt 1977) and Revised Universal Soil Loss Equation (RUSLE; Renard et al. 1997) are not good predictors of fluvial suspended sediment concentrations and loads.

A relation between specific sediment yield (SSY) and drainage basin area has been defined by Roehl (1962) and Vanoni (1975) as the following equation:

$\mathrm{SSY}=\alpha \mathrm{A}^{-\beta}$,

where SSY is specific sediment yield $(\mathrm{Mg}$ $\left.\mathrm{km}^{-2} \mathrm{y}^{-1}\right), \mathrm{A}$ is basin area $\left(\mathrm{km}^{2}\right)$, and $\alpha$ and $\beta$ are empirical parameters. The generally accepted negative relation between SSY and basin area, which is based on several studies in areas strongly impacted by human activities (Walling and Webb 1996), is explained by the trapping of eroded sediment at the foot of slopes; along ephemeral waterways; and in wetlands, alluvial plains, and other sinks. However, other studies have shown a positive relation between SSY and basin area, which suggests that the relative contributions of sediment from channel sources is more important than the contribution from fields and upland sources (Church and Slaymaker 1989; Lu et al.2005). In some cases, a positive relation may also be found where erodible land occurs in the middle section of the drainage basin (Jiongxin and Yunxia 2005). A more complex relation between SSY and basin area has been proposed by de Vente et al. (2007) based on several cases studied from around the world. Osterkamp and Toy (1997), working in semiarid and humid environments in the United States, proposed a model with three different relations between basin area and SSY. At small scales $(<0.01$ $\left.\mathrm{km}^{2}\left[0.004 \mathrm{mi}^{2}\right]\right)$ where the dominant erosive process is splash and sheet erosion, SSY does not increase with basin area. For basin areas of 0.01 to $1 \mathrm{~km}^{2}$ (0.004 to $\left.0.39 \mathrm{mi}^{2}\right)$, SSY and basin area have a positive relation because of erosive processes, such as rills, gul- lies, fluvial channel erosion, and landslides. At scales greater than $1 \mathrm{~km}^{2}\left(0.39 \mathrm{mi}^{2}\right)$, the relation between basin area and SSY is negative due to a decrease in slope gradient resulting in an increase in the area of flood plain available for sediment deposition and less potential for erosive processes. Additionally, rainfall and geology variation that may occur at larger spatial scales can be an important factor in the relation between SSY and basin area.

This paper compares the effects of weather, hydrology, basin size, fluvial geomorphology aspects, and agricultural practices on SSY in two river basins, the Iowa River basin (IRB) in central Iowa and the Yazoo River basin (YRB) in northwestern Mississippi, both tributaries of the Mississippi River. Despite short monitoring time and variability in the results, we found evidence that suggests measured SSY was affected by scale and land use.

\section{Materials and Methods}

As part of the US Geological Survey (USGS), National Water-Quality Assessment (NAWQA) Program, water samples were collected from 2006 through 2008 to investigate the sources, transport, and fate of agricultural chemicals in the South Fork Iowa River basin in north-central Iowa (a subwatershed within the IRB) and the Bogue Phalia (BP) basin of northwestern Mississippi (a subwatershed within the YRB; figure 1). The South Fork Iowa River (SFIR) basin in Iowa is representative of the midwestern United States where much of the agricultural land is used for corn (Zea mays L.) and soybean (Glycine max L.) row cropping (Kalkhoff and Capel 2005). The $\mathrm{BP}$ basin in Mississippi is representative of the Mississippi River alluvial plain where most agricultural land is cropped with soybean, cotton (Gossipium hirsutum L.), rice (Oryza sativa), and corn in a humid, subtropical area of the United States (Coupe and Capel 2005).

Study Sites-Iowa. Site Iowa-4 (32,375 $\mathrm{km}^{2}$ [12,500 $\left.\mathrm{mi}^{2}\right]$; site no. 4 in figure 1 and table 1) is located below the confluence of the Cedar River with the Iowa River and drains the IRB northwest to southeast across eastern Iowa (figure 1). The Iowa River originates in north-central Iowa and flows through land that is predominantly covered by row-crop agriculture, and is an important area for livestock production, particularly swine (Linhart and Eash 2010). Although Iowa-4 includes drainage from older glacial landforms, as well as agricultural lands, data from this site were included here to represent changes in sediment dynamics associated with larger, low-gradient rivers in the upper Mississippi River basin.

The SFIR basin, which lies within the IRB, drains approximately $580 \mathrm{~km}^{2}(224$ $\left.\mathrm{mi}^{2}\right)$ at the monitoring site located northeast of New Providence, Iowa (Iowa-3; site no. 3 in figure 1 and table 1). Most of the SFIR basin lies within Hamilton and Hardin counties, Iowa. The basin has low relief with common glacial depressions (potholes) that before human settlement were covered by ponds and wetlands, and are now drained by subsurface drainage, surface inlets, and ditches to facilitate agricultural production. The smaller basins used in this study, which lie within the SFIR basin, were Williams Township (TWSP) Runoff-1 near Blairsburg, Iowa (Iowa-1; site no. 1 in figure 1 and table 1), and SFIR near Blairsburg, Iowa (Iowa-2; site no. 2 in figure 1 and table 1). Streamflow at Iowa-1 and -2 is mainly from subsurface (tile) drains, compared to overland flow and groundwater flow contributions to streamflow at Iowa-3 (Simon and Klimt 2008; Tomer et al. 2010). Average annual precipitation in the SFIR basin is approximately $800 \mathrm{~mm}$ (31.5 in), and about $25 \%$ of the precipitation becomes runoff (Kalkhoff et al. 2000). The dominant soil association is the Clarion (well-drained Typic Hapludolls), Nicollet (poorly drained Aquic Hapludolls), and Webster (poor drained Aquic Hapludolls; Karlen et al. 2008), which is typical of the Des Moines lobe, a landform region in north-central Iowa formed by Wisconsinage glaciation (approximately 12,000 years ago). A conservation practice inventory for the South Fork of the Iowa River (Tomer et al. 2008) describes that $85 \%$ of the watershed fields are cultivated in a crop sequence with corn and soybean. Grassed waterways and riparian buffers are common edge-of-field practices to control runoff. Conventional tillage, mulch or ridge tillage, and no-tillage were practiced in $29 \%, 58 \%$, and $7 \%$ of the watershed, respectively, at the time of the 2005 survey. Poor surface residue following soybean cultivation was identified as a main soil management problem to control soil and runoff losses (Tomer et al. 2008).

Study Sites-Mississippi. Site Yazoo-4 $\left(34,589 \mathrm{~km}^{2}\right.$ [13,355 $\left.\mathrm{mi}^{2}\right]$; site no.8 in figure 1 and table 1) drains land that is divided almost equally between lowlands in the Mississippi Delta, which is almost entirely 


\section{Figure 1}

Location of the study area sampling sites in the lowa River basin, lowa, and Yazoo River basin in Mississippi.

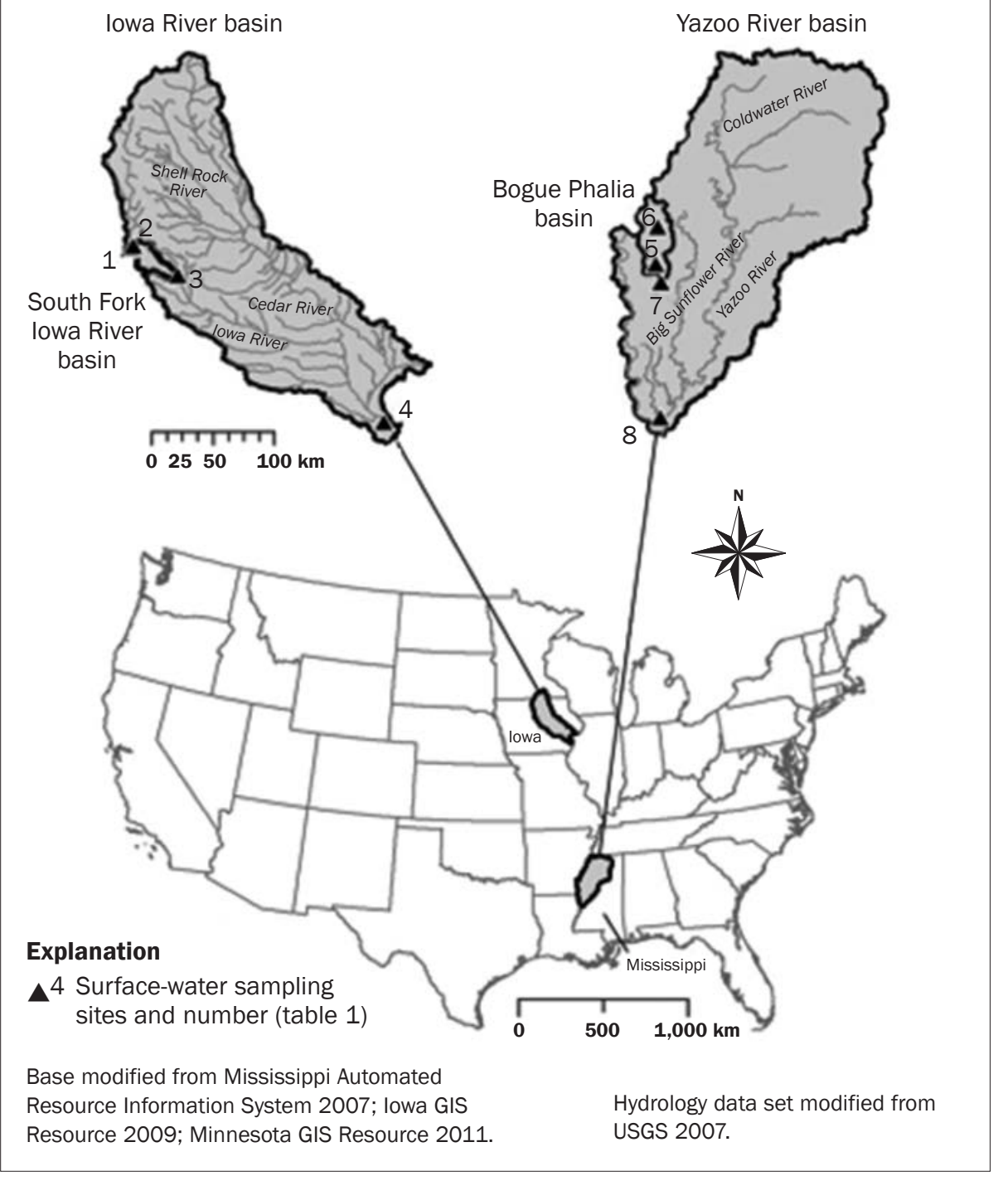

agricultural in use, and the uplands, which generally consists of forest, pastures, and small farms (Coupe 2002; Locke et al. 2008). Land use in the YRB is predominantly agricultural (51\%), followed by forested (29\%), and wetlands (10.5\%; Coupe 2002). Although drainage at Yazoo-4 includes the uplands area of the basin, data are included in this study to represent sediment dynamics associated with larger rivers in the lower Mississippi River basin.

The BP basin $\left(1,250 \mathrm{~km}^{2}\right.$ [483 $\mathrm{mi}^{2}$; Yazoo-3) lies within the YRB (site no. 7 in figure 1 and table 1). Most of the BP basin is located in Bolivar County, Mississippi. Subbasin sampling sites within the BP basin include an unnamed tributary Clear Creek near Napanee, Mississippi (Yazoo-1; site no. 5 in figure 1 and table 1), and Tommie Bayou at Pace, Mississippi (Yazoo-2; site no. 6 in figure 1 and table 1). Cotton and corn are planted in Dundee soils (fine-silty, mixed, active, thermic Typic Endoaqualfs), which are loam textured and occupy terraces and natural levees. Dundee soils have better drainage than the Sharkey clay (very-fine, smectitic, thermic Chromic Epiaquerts), which occurs in flood-prone lowlands and tends to retain water for long periods of time (Soil Survey Staff 1999). Annual precipitation in the BP basin ranges from 1,140 to $1,500 \mathrm{~mm}(44.8$ to 59 in; Pettry 1977), about $40 \%$ to $50 \%$ of which returns to the stream as overland flow (Yuan et al. 2008; Shaw et al. 2006; Rebich and Knight 2001). There is little topographic relief in the BP basin, but runoff from the fine-textured soils rapidly enters streams and rivers from agricultural fields. The agricultural conservation practices installed in this watershed include no-tillage, grassed waterways, surface drainage control structures (e.g., slotted risers used during rice production), edge-of-field filter strips, and riparian buffers, which can successfully reduce the movement of agricultural chemicals and sediment from fields (Yuan and Bingner 2002; Coupe and Capel 2005; Locke et al. 2008; Knight et al. 2013).

Data Collection and Analysis. Water samples from Iowa-2, Iowa-3, Iowa-4, Yazoo-2, Yazoo-3, and Yazoo-4 (table 1) were collected from 2006 to 2008 using a standard isokinetic sediment sampler as described by Edwards and Glysson (1999). In addition to sample data collected during this study period, historical data for Iowa-3, Iowa-4, Yazoo-3, and Yazoo-4, collected between 1996 and 2008, were also used to compare with our study period analysis. Samples from Iowa-4 and Yazoo-4 were collected monthly. Samples from Iowa-3 and Yazoo-3 were collected on a regular schedule, bimonthly during most of the year but weekly during the growing season (May to August); additional samples (about $20 \%$ to $30 \%$ of the total samples) were collected from Iowa-3 and Yazoo-3 during storm events. For the four small subbasins (Iowa-1, Iowa-2, Yazoo-1, and Yazoo-2; table 1), samples were collected using an automatic sampler triggered by a datalogger connected to a pressure transducer that measured water depth in the stream. A rise in stage to a predetermined stream level initiated the automatic samplers to collect samples at a fixed interval, which varied from site to site depending upon the hydrologic characteristics of the site. The point samples collected with the automatic sampler were periodically checked and calibrated against depth- and width-integrated samples collected at the four small sites. Suspended sediment concentration (SSC) analysis for the Mississippi water samples was performed by the USGS Sedimentation Laboratory in Baton Rouge, Louisiana, and for the Iowa water samples at the USGS Sedimentation Laboratory in Iowa City, Iowa. All samples were analyzed according to the method described by Guy (1969). The mean daily discharge $(\mathrm{Q})$ for Iowa-2, Iowa3, Iowa-4, Yazoo-2, Yazoo-3 and Yazoo-4 (and the subdaily discharge for Iowa-1 and Yazoo-1) was calculated using a continuous 


\section{Table 1}

Sites sampled in two agricultural river basins in lowa and Mississippi.

\begin{tabular}{|c|c|c|c|c|c|c|c|c|c|c|c|c|c|c|}
\hline \multirow{2}{*}{$\begin{array}{l}\text { Site } \\
\text { number } \\
\text { (figure 1) }\end{array}$} & \multirow[b]{2}{*}{ Station name } & \multirow[b]{2}{*}{$\begin{array}{l}\text { Site } \\
\text { name }\end{array}$} & \multirow[b]{2}{*}{$\begin{array}{l}\text { USGS site } \\
\text { number }\end{array}$} & \multirow[b]{2}{*}{$\begin{array}{l}\text { Area } \\
\left(\mathrm{km}^{2}\right)\end{array}$} & \multirow[b]{2}{*}{$\begin{array}{l}\text { Samples } \\
(n)\end{array}$} & \multirow[b]{2}{*}{$\begin{array}{l}\text { Sampling } \\
\text { year }\end{array}$} & \multicolumn{4}{|c|}{ Discharge $\left(\mathrm{m}^{3} \mathrm{~s}^{-1}\right)$} & \multicolumn{4}{|c|}{$\begin{array}{l}\text { Suspended sediment } \\
\text { concentration }\left(\mathrm{mg} \mathrm{L}^{-1}\right)\end{array}$} \\
\hline & & & & & & & Min & Max & Avg & Med & Min & Max & Avg & Med \\
\hline 1 & $\begin{array}{l}\text { Williams TWSP Runoff-1 } \\
\text { near Blairsburg, lowa* }\end{array}$ & lowa-1 & $\begin{array}{c}42313509 \\
337301\end{array}$ & 2.3 & 16 & 2008 & 0 & 0.4 & 0.1 & 0.07 & 104 & 5,170 & 1,305 & 838 \\
\hline 2 & $\begin{array}{l}\text { South Fork lowa River } \\
\text { near Blairsburg, lowa }\end{array}$ & lowa-2 & 05451080 & 31 & 81 & 2006 to 2008 & 0.001 & 16 & 0.45 & 0.2 & 3 & 3,990 & 320 & 69 \\
\hline 3 & $\begin{array}{l}\text { South Fork lowa River NE } \\
\text { at New Providence, lowa }\end{array}$ & lowa-3 & 05451210 & 580 & 169 & 2006 to 2008 & 0.25 & 167 & 9 & 3 & 8 & 740 & 131 & 96 \\
\hline 4 & $\begin{array}{l}\text { lowa River at Wapello, } \\
\text { lowa }\end{array}$ & lowa-4 & 05465500 & 32,375 & 375 & 1996 to 2008 & 23 & 4,871 & 282 & 166 & 4 & 2,650 & 200 & 123 \\
\hline 5 & $\begin{array}{l}\text { Unnamed tributary } \\
\text { Clear Creek near } \\
\text { Napanee, Mississippi† }\end{array}$ & Yazoo-1 & $\begin{array}{c}333150090 \\
530400\end{array}$ & 2.2 & 58 & 2007 to 2008 & 0 & 2 & 0.08 & 0.007 & 77 & 3,340 & 518 & 331 \\
\hline 6 & $\begin{array}{l}\text { Tommie Bayou at Pace, } \\
\text { Mississippi }\end{array}$ & Yazoo-2 & 07288636 & 15 & 37 & 2007 to 2008 & 0.001 & 123 & 0.46 & 0.08 & 52 & 1,823 & 435 & 318 \\
\hline 7 & $\begin{array}{l}\text { Bogue Phalia near } \\
\text { Leland, Mississippi }\end{array}$ & Yazoo-3 & 07288650 & 1,254 & 200 & 2007 to 2008 & 0.11 & 207 & 16 & 3 & 24 & 1,554 & 230 & 153 \\
\hline 8 & $\begin{array}{l}\text { Yazoo River below Steele } \\
\text { Bayou near Long Lake, } \\
\text { Mississippi }\end{array}$ & Yazoo-4 & 07288955 & 34,589 & 194 & 1996 to 2008 & 21 & 1,473 & 355 & 246 & 28 & 3,243 & 268 & 156 \\
\hline
\end{tabular}

Notes: USGS = US Geological Survey. Min = minimum. Max = maximum. Avg = average. Med = median.

*Surface runoff from field through a culvert.

†Sampled from a permanent ditch within an agricultural field that has multiple culverts for drainage.

record of stage for all sites and reported by the USGS according to standard procedures (Rantz 1982). Data used in support of this paper are available from the USGS National Water Information System (http://waterdata.usgs.gov/nwis).

Sediment Rating Curves and Load Estimates. Daily SSC in Iowa-2, Iowa3, Iowa-4, Yazoo-2, Yazoo-3, and Yazoo-4, and instantaneous SSC for watersheds Iowa-1 and Yazoo-1, was calculated using the sediment-rating curve procedure described in detail by Horowitz et al. (2001) and Horowitz $(2003,2010)$.

Values of SSC and Q collected during the study period (table 1) were log-transformed and a single sediment rating curve was generated for each site (equation provided in table 2). Horowitz (2003) stated that a reasonable estimate of annual sediment flux using the rating- curve method can be reached when at least 12 sediment samples are collected using a calendar and hydrology-based sampling schedule and when these collected samples cover $80 \%$ of the flow variation that occurs over a year. Sediment samples collected at all of the study sites covered $80 \%$ of the flow variation that occurs over a year historically at each site.

Linear and polynomial regression equations were evaluated for each sediment rating curve. Estimated daily SSCs were then generated from each regression equation and daily sediment load was calculated, according to equation 2 :

$q s s=\mathrm{Q} \times \mathrm{SSC} \times 0.00245$,

where qss represents daily sediment load $\left(\mathrm{t} \mathrm{d}^{-1}\right), \mathrm{Q}$ is the daily discharge $\left(\mathrm{ft}^{3} \mathrm{~s}^{-1}\right)$, SSC is the daily suspended sediment concentration ( $\mathrm{mg} \mathrm{L}^{-1}$ ), and 0.00245 is a constant used to convert qss to metric units (Porterfield 1977).

The conversion from log space to arithmetic space (to calculate daily sediment load) can produce a bias that can be compensated for by applying a "smearing" correction when log values are converted back to the arithmetic scale (Duan 1983). The daily sediment load from each curve was added to produce four measures of annual load: (1) linear regression without smearing correction, (2) linear regression with smearing correction, (3) polynomial regression without smearing correction, (4) and polynomial regression with smearing correction. These four different loads were compared with the sediment load for the calibration data set. The difference between measured SSC and calculated SSC for each equation was $\leq 20 \%$, which is considered acceptable when computing sediment flux using an adjusted regression model according to Horowitz (2003), and the equation with the total estimated load closest to that of the calibration data set was then used to predict daily SSC for all mean daily $Q$ values at each site (the selected regression equations are listed in table 2). Finally, the annual sediment load was calculated by adding the appropriate number of daily qss values.

Flow-weighted SSCs (FWC) (Horowitz 2010) were determined using the following equation:

$$
\mathrm{FWC}=\frac{\mathrm{ASL}}{\mathrm{TAVD}} \times 10^{6},
$$

where FWC represents flow-weighted concentration $\left(\mathrm{mg} \mathrm{L}^{-1}\right), \mathrm{ASL}$ is annual sediment load $(\mathrm{Mg})$, and TAVD is total annual volume of discharge $\left(\mathrm{m}^{3}\right)$.

The SSY ( $\mathrm{Mg} \mathrm{km}^{-2} \mathrm{y}^{-1}$; table 3$)$ for all eight sites was estimated by dividing the sed- 


\section{Table 2}

The best-fit rating curve model for the eight basins in lowa and Mississippi.

\begin{tabular}{lclll}
\hline Site & Area $\left.\mathbf{( k m}^{2}\right)$ & Adjusted regression model & Equation & Significance (\%) \\
\hline lowa-1 & 2.3 & Polylinear with smearing factor & $\mathrm{SSC}=-0.1391 \mathrm{Q}^{2}-0.3602 \mathrm{Q}+2.718$ & $\mathrm{NS}$ \\
lowa-2 & 31 & Polylinear with smearing factor & $\mathrm{SSC}=0.0783 \mathrm{Q}^{2}+0.0737 \mathrm{Q}+1.670$ & $>95$ \\
lowa-3 & 580 & Linear with smearing factor & $\mathrm{SSC}=0.5594 \mathrm{Q}+0.689$ & $>99$ \\
lowa-4 & 32,375 & Linear & $\mathrm{SSC}=0.2234 \mathrm{Q}+1.218$ & $>95$ \\
lowa-4* & 32,375 & Linear & $\mathrm{SSC}=0.6436 \mathrm{Q}-0.457$ & $>99$ \\
Yazoo-1 & 2.2 & Polylinear with smearing factor & $\mathrm{SSC}=0.2192 \mathrm{Q}^{2}-0.2918 \mathrm{Q}+2.525$ & $\mathrm{NS}$ \\
Yazoo-2 & 15 & Polylinear & $\mathrm{SSC}=0.2209 \mathrm{Q}^{2}-0.7278 \mathrm{Q}+2.97$ & $\mathrm{NS}$ \\
Yazoo-3 & 1,254 & Polylinear with smearing factor & $\mathrm{SSC}=0.066 \mathrm{Q}^{2}-0.0444 \mathrm{Q}+1.898$ & $>99$ \\
Yazoo-4 & 34,589 & Polylinear with smearing factor & $\mathrm{SSC}=0.3081 \mathrm{Q}^{2}-2.0925 \mathrm{Q}+5.434$ & $>95$ \\
Yazoo-4* & 34,589 & Polylinear with smearing factor & $\mathrm{SSC}=0.1288 \mathrm{Q}^{2}-0.6227 \mathrm{Q}+2.614$ & $>99$ \\
\hline
\end{tabular}

Notes: SSC = suspended-sediment concentration. Q = discharge. NS = not significant at a 5\% confidence level.

*Data to generate rating curve is from 1996 to 2008, a 13-year time period.

iment yield $\left(\mathrm{Mg} \mathrm{y}^{-1}\right)$ by the watershed area $\left(\mathrm{km}^{2}\right)$. This information was then combined to estimate the scaling relationships in the basins. To estimate SSY values for watersheds smaller than the stream initiation threshold $\left(<3 \mathrm{~km}^{2}\left[<1.2 \mathrm{mi}^{2}\right]\right)$, we found past studies that evaluated SSY in small watersheds (approximately $0.1 \mathrm{~km}^{2}\left[0.04 \mathrm{mi}^{2}\right]$ ) within the IRB and YRB basins that used field experiments and mathematical modeling to determine sediment yields under different cropping and tillage systems to evaluate historical sediment contributions from uplands. The data from these additional studies provide good context to evaluate sediment sources from uplands in these two basins and the impact of management.

\section{Results and Discussion}

Precipitation and Discharge. Table 4 provides information about precipitation, annual rain erosivities, runoff coefficients, and turbidity for the IRB and YRB. Annual rain erosivity and runoff coefficient values are applicable for the three smaller watersheds in each basin. Long-term average precipitation for the YRB is 1.6 times greater than for the IRB. Annual rain erosivity and runoff coefficients are also higher in the YRB (2.6 and 2 times greater, respectively) than in the IRB (table 4). The annual precipitation for the IRB in $2006(882 \mathrm{~mm}$ [34.7 in]) was similar to its long-term average (800 $\mathrm{mm}$ [31.5 in]). However, in 2007 and 2008, IRB annual precipitation was $46 \%$ and $55 \%$, respectively, greater than the long-term average $(1,171 \mathrm{~mm}$ and $1,237 \mathrm{~mm} \mathrm{[46.1} \mathrm{in}$ and $48.7 \mathrm{in}$ ] versus $800 \mathrm{~mm}$ ). In contrast, the YRB in 2007 and 2008 had annual precipitation of $849 \mathrm{~mm}$ and $1,240 \mathrm{~mm}(33.4$ in and 48.8 in), respectively (i.e., $35 \%$ less in
2007 and 6\% less in 2008 compared to the long-term average of $1,320 \mathrm{~mm}$ [51.9 in]) Seasonally, precipitation and discharge in the IRB is concentrated in spring and early summer, largely coinciding with the time when soil is most susceptible to rain erosion because of limited soil cover by seedlings and emerging crops (Tomer et al 2008). In the YRB, most precipitation and runoff occurs late fall through May (Yuan and Bingner 2002), with summer and early fall being relatively drier.

The TAVD for the eight gaged watersheds is presented in table 3. Additionally, historical data for a 13-year period (1996 to 2008) for the Iowa-4 and Yazoo-4 sites were used to evaluate differences in hydrological patterns over a longer time span (figures $2 \mathrm{a}$ and $2 \mathrm{~b}$ ) than the two- to three-year study period.

For the Iowa-4 site, the TAVD in 2006 was 43\% less, while in 2007 and 2008 the annual volumes of discharge were $38 \%$ and $84 \%$ greater, respectively, compared to the 13-year average TAVD (table 3 ). That is, during this study, the IRB had two years with annual volume of discharge above the average and one year with below average annual volume of discharge (figure 2a). From December of 2007 through June of 2008, much of the IRB was subjected to unusually large rainfall events. December to May was the second wettest sixmonth period followed by the second wettest June since records began in 1895 (Hubbard et al. 2011).

The Yazoo River (Yazoo-4) had an annual volume of discharge in 2007 and 2008 that was respectively $48 \%$ and $22 \%$ lower than the 13-year average (table 3).

Suspended Sediment Concentration and Yields. The Yazoo-4 site had an average 13-year SSY that was 2.6 times higher than
Iowa-4 (149 versus $60 \mathrm{Mg} \mathrm{km}{ }^{-2} \mathrm{y}^{-1}$ [425.4 versus $171.3 \mathrm{tn} \mathrm{mi}^{-2} \mathrm{yr}^{-1}$ ]; table 3$)$. However, for the study period (2007 to 2008), Yazoo-4 and Iowa-4 had similar specific sediment yields (59 versus $60 \mathrm{Mg} \mathrm{km}^{-2} \mathrm{y}^{-1}$ [168.4 versus $\left.171.3 \mathrm{tn} \mathrm{mi}^{-2} \mathrm{yr}^{-1}\right]$ ), probably due to above average precipitation in Iowa. The 2006 SSY in Iowa-4 (21 Mg km${ }^{-2} \mathrm{y}^{-1}$ [60 tn $\left.\mathrm{mi}^{-2} \mathrm{yr}^{-1}\right]$ ) was $65 \%$ less than the 13 -year average, the lowest of the three-year observation period. In 2008, however, the extreme wet conditions during spring and summer increased the Iowa-4 SSY to 1.6 times higher than the 13-year average SSY. In Yazoo-4, there was relatively dry weather during the study period (especially in 2007). The SSY for 2007 and 2008 was $72 \%$ and $48 \%$ less, respectively, than the 13-year average (figure $2 b$ ).

The FWCs are greater for Yazoo-2, -3 , and -4 compared to Iowa-2, -3 , and -4 (table 3 ). However, FWC at the Iowa-1 site was greater than the FWC at the Yazoo-1 site (table 3). Discharge at Iowa-1 mainly consisted of overland flow and shallow subsurface flow through tile drains from an agricultural field through a culvert; thus, samples were collected only after extreme rainfall events (in 2008) since these were the only times the watershed had discharge.

The FWC did not change substantially over the two-year study period for any of the YRB sites, although the TAVD was lower in 2007 than in 2008 (table 3). The FWC at all of the IRB sites had an increasing trend over the three years because the TAVD had an increasing trend.

The Specific Sediment Yield Scale Effect. In the YRB (Yazoo-1, -2, -3, and -4), the SSY and watershed area were inversely related (table 3). In the IRB (table 3), a different relationship was observed. The SSY appeared greatest in the two intermedi- 
Table 3

Summaries of total annual volume of discharge (TAVD), specific sediment yield (SSY), and average flow-weighted suspended sediment concentrations (FWC) in the eight basins within the lowa and Mississippi.

\begin{tabular}{|c|c|c|c|c|c|}
\hline Site & $\begin{array}{l}\text { Basin area } \\
\left(\mathbf{k m}^{2}\right)\end{array}$ & Sampling period & $\operatorname{TAVD}\left(\mathrm{m}^{3}\right) \times 10^{6}$ & SSY (Mg km-2 $\left.\mathrm{y}^{-1}\right)$ & FWC (mg L-1) \\
\hline lowa-1 & 2.3 & 2008 & 0.1 & 35 & 1,250 \\
\hline \multirow[t]{4}{*}{ lowa-2 } & 31 & 2006 & 6.7 & 49 & 228 \\
\hline & & 2007 & 15.2 & 146 & 297 \\
\hline & & 2008 & 15.4 & 195 & 395 \\
\hline & & 3-year average & 12.4 & 130 & 307 \\
\hline & & 2008 & 359 & 218 & 353 \\
\hline & & 3-year average & 275 & 137 & 253 \\
\hline \multirow[t]{3}{*}{ lowa-4 } & 32,375 & 2006 & 5,532 & 21 & 124 \\
\hline & & 2007 & 13,340 & 61 & 148 \\
\hline & & 2008 & 17,756 & 94 & 171 \\
\hline \multirow{2}{*}{ Yazoo-1 } & & 2008 & 2.4 & 613 & 258 \\
\hline & & 2-year average & 1.7 & 396 & 315 \\
\hline \multirow[t]{3}{*}{ Yazoo-2 } & 15 & 2007 & 4.4 & 98 & 328 \\
\hline & & 2008 & 15.2 & 381 & 376 \\
\hline & & 2-year average & 9.8 & 240 & 352 \\
\hline \multirow[t]{3}{*}{ Yazoo-3 } & 1,253 & 2007 & 296 & 76 & 322 \\
\hline & & 2008 & 574 & 164 & 358 \\
\hline & & 2-year average & 435 & 120 & 340 \\
\hline \multirow[t]{2}{*}{ Yazoo-4 } & 34,589 & 2007 & 7,971 & 42 & 184 \\
\hline & & 2008 & 11,823 & 77 & 225 \\
\hline
\end{tabular}

Table 4

Precipitation, rain erosivity, runoff coefficient, and turbidity for the lowa River and Yazoo River basins.

\begin{tabular}{lcc}
\hline Basin characteristics & lowa River basin & Yazoo River basin \\
\hline Precipitation (mm)* & & \\
2006 & 882 & 1,278 \\
2007 & 1,171 & 849 \\
2008 & 1,237 & 1,240 \\
$\quad$ Long term average (1996 to 2008) & 800 & 1,320 \\
Annual rain erosivity (MJ mm ha $\left.{ }^{-1} \mathrm{~h}^{-1} \mathrm{y}^{-1}\right) \dagger$ & 2,805 & 7,370 \\
Annual runoff coefficent $\ddagger($ unitless) & 0.25 & 0.50 \\
Median annual turbidity (NTU)§ & 39 & 90 \\
\hline
\end{tabular}

Note: NTU = nephelometric turbidity units.

* NOAA (2013) and MSU Extension Service (2006). Precipitation averages in the lowa River basin were calculated using the following precipitation stations: Williams, Hubbard, lowa Falls, Webster City, and Webster City 2 S. Precipitation averages in the Yazoo River basin were calculated using the following precipitation stations: Clarksdale, Cleveland, Greenville, and Stoneville.

†Whischmeier and Smith (1978).

$\ddagger$ Kalkhoff et al. (2000) and Shaw et al. (2006).

§US Geological Survey (2014). Average turbidity at lowa-4 and Yazoo-4, respectively, over the study period. ate-sized watersheds (Iowa-2 and Iowa-3) and then decreased in the largest watershed (Iowa-4). The SSY at the Iowa-1 site was of intermediate magnitude for the one year of data collection (2008).

Sediment yield from a watershed results from a balance of erosion and depositional processes that are naturally occurring and scale-dependent, but the balance can be greatly altered by human activities, such as land-use changes, stream channelization, and dam construction. Rainfall, especially at times of greater soil vulnerability (late spring to early summer), is an important driver for sediment movement in agricultural basins. Extreme hydrologic events, such as floods, can often overwhelm typical agricultural management practices, resulting in concurrent high yields of sediment and agricultural chemicals, such as pesticides and phosphorus $(\mathrm{P})$, associated with that sediment. Conversely, periods of lower than normal 


\section{Figure 2}

Specific sediment yield (SSY) and total annual volume of discharge at (a) lowa-4 and (b) Yazoo-4.

(a)

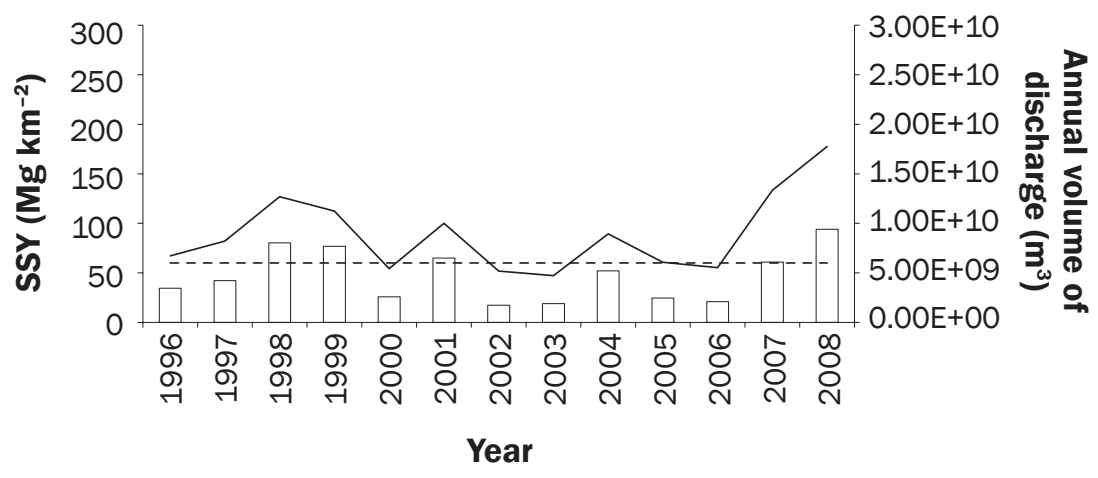

Legend

lowa-4 SSY --- lowa-4 average SSY _ lowa-4 annual flow volume

(b)

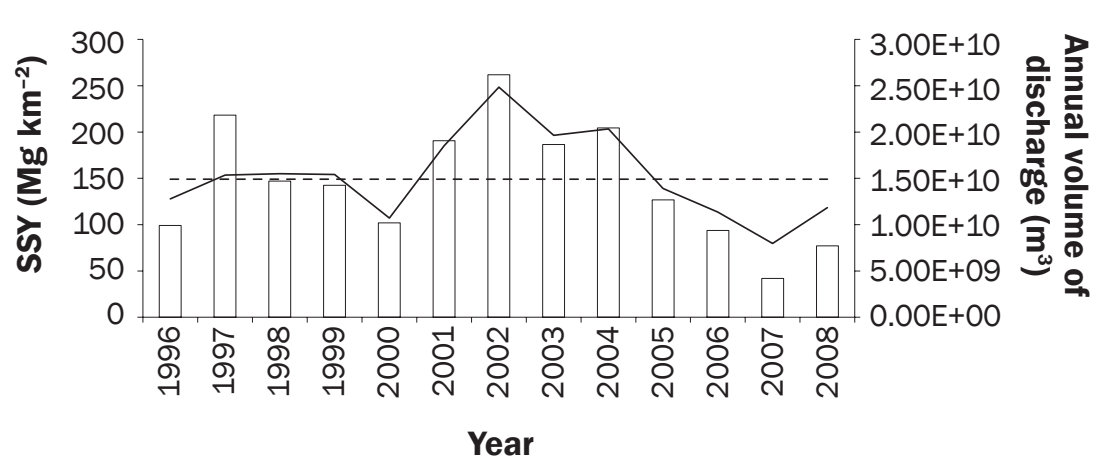

Legend

\Yazoo-4 SSY - - - Yazoo-4 average SSY — Yazoo-4 annual flow volume

rainfall can result in lower than average SSY from a basin.

Comparison of the Specific Sediment Yield from the Yazoo and Iowa River Basins. Sediment yields were higher in the three smallest watersheds within the YRB than the three smallest watersheds within the IRB (table 3) for the two- to three-year study period. Under normal annual discharge conditions, SSY from Yazoo-4 is almost three times greater than the SSY from Iowa-4. However, average SSY for the two- to threeyear study period at these sites was nearly the same (60 to $59 \mathrm{Mg} \mathrm{km}^{-2} \mathrm{y}^{-1}$ [171.3 to $168.4 \mathrm{tn} \mathrm{mi}^{-2} \mathrm{yr}^{-1}$ ], respectively). The lack of difference between SSY at the two largest sites is likely because the YRB experienced less than normal precipitation during 2007, whereas the IRB had higher than normal precipitation in both 2007 and 2008, which resulted in two years of higher than average annual discharge (table 3 ).
Higher yield on average from the YRB can be attributed to more erosive rains, higher soil erodibility, and higher runoff coefficients than in the IRB (table 4). Two additional factors contribute to the difference in SSY between these basins. First, subsurface tile drainage is the dominant transport pathway of water from fields to streams in the IRB. These flows drain shallow groundwater, which carries little sediment. Most of the sediment in the YRB is transported from fields to streams through overland flow, which carries a high concentration of sediment after rainfall. According to the USDA $(2010,2013)$, structural practices for controlling soil erosion from water movement are used in $42 \%$ of cropped areas in the upper Mississippi River basin (which includes the IRB), but are used only on $21 \%$ of cropped areas in the lower Mississippi River basin (which includes the YRB). This suggests that agricultural impacts on soil erosion and the greater sediment yield observed in the $\mathrm{YRB}$, as compared to the
IRB, are consistent with its higher soil erosion potential and fewer structural practices for controlling water erosion.

Sediment Rating Curves. The shape of the sediment rating curves for Iowa- 4 and Yazoo-4 (figures 3 and 4, respectively) give some insight into the difference in fluvial dynamics between the IRB and YRB. The relation between $\log$ SSC and $\log$ Q at Yazoo-4 had greater heteroscedasticity than the relation at Iowa-4, meaning that there was more variability in $\log$ SSC as discharge increased at Yazoo-4 (figures $3 \mathrm{a}$ and $3 \mathrm{~b}$ and figures $4 a$ and $4 b$ ). At lower discharges, SSCs are higher at Yazoo-4 than at Iowa-4. In part, the concentration differences can be attributed to the dissimilarities in grain sizes of the transported sediment. Fluvial sediments measured in water samples from Yazoo-4 are predominantly fine-grained silts and clays (Dendy 1981; Murphree et al. 1985) with low settling velocities; as a result, these sediments can be transported over large distances, as shown by the high turbidity characteristics of the Yazoo River (median turbidity for the study period was 90 nephelometric turbidity units [NTU; table 4]). For Iowa-4, however, sediment grain sizes are larger (fine clay, silt, and sands [USGS 2014]), so higher stream velocities are needed to carry the sediment (median turbidity for the study period was 39 NTU [table 4]). Geomorphological differences between the two basins also account for differing fluvial dynamics. In the IRB, the river valleys were carved by glacial meltwater and then filled with coarse outwash gravels resulting in a streambed resistant to downcutting. In contrast, streambeds in the YRB consist of fine-grained sand, silts, loess, and clays that are more susceptible to downcutting.

Some authors, such as Sichingabula (1998), Asselman (2000), and Horowitz (2003 and 2008), have related the shape of a sediment rating curve to hydrological processes acting within a basin. Different shapes between the curves for Iowa-4 and Yazoo-4 indicate that different processes are occurring in the two basins. The rating-curve shape for Iowa-4 (figure 3) is slightly convex, an indicator that the systems contributing to the Iowa River were "sediment-starved" during the 2006 to 2008 time period. Horowitz (2003) noted that floods remove a substantial amount of bed sediment from a river, which is a major source of SSC and can result in a convex-shaped rating curve because scouring of a stream limits sediment supply. In both 2007 
Figure 3

Sediment rating curves for lowa River at Wapello (lowa-4) for the time period (a) 1996 to 2008 and (b) 2006 to 2008.

(a)

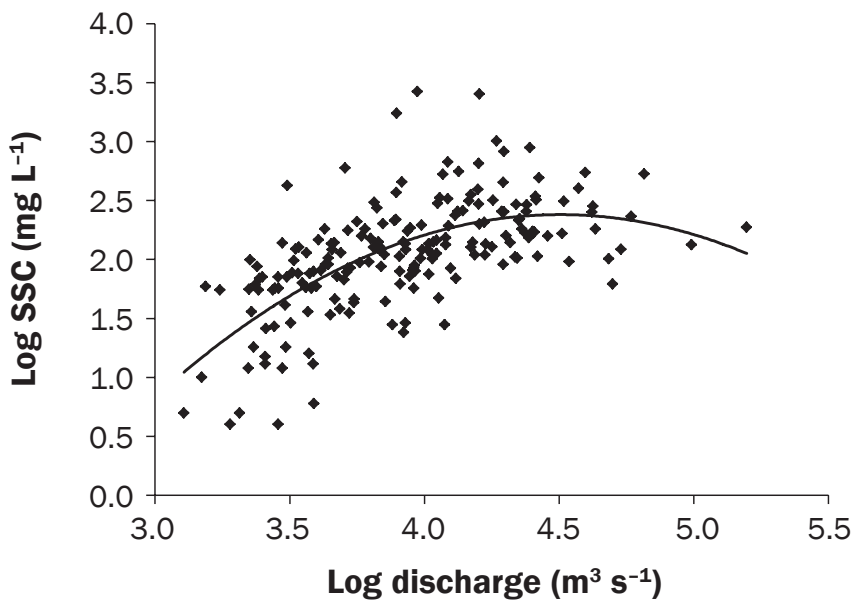

(b)

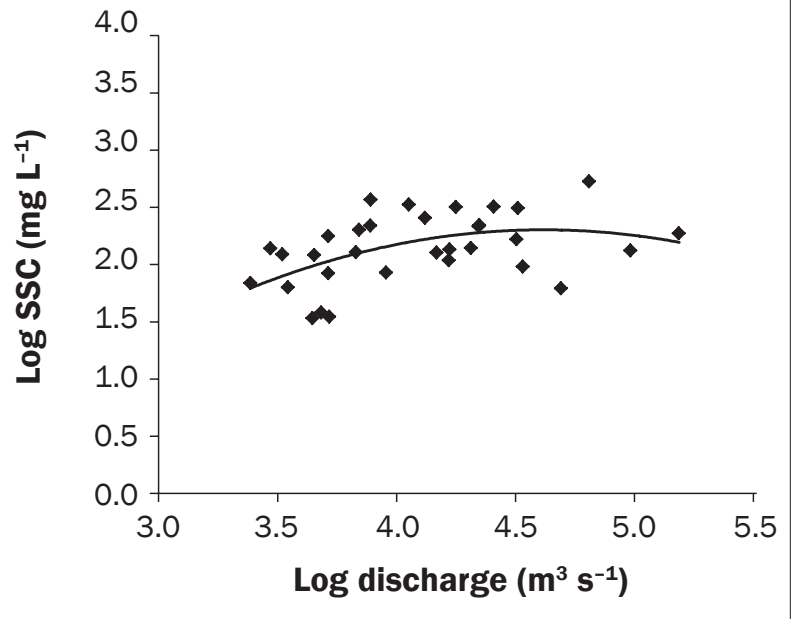

\section{Figure 4}

Sediment rating curves for Yazoo River near Long Lake (Yazoo-4) for the time period (a) 1996 to 2008 and (b) 2006 to 2008.

(a)

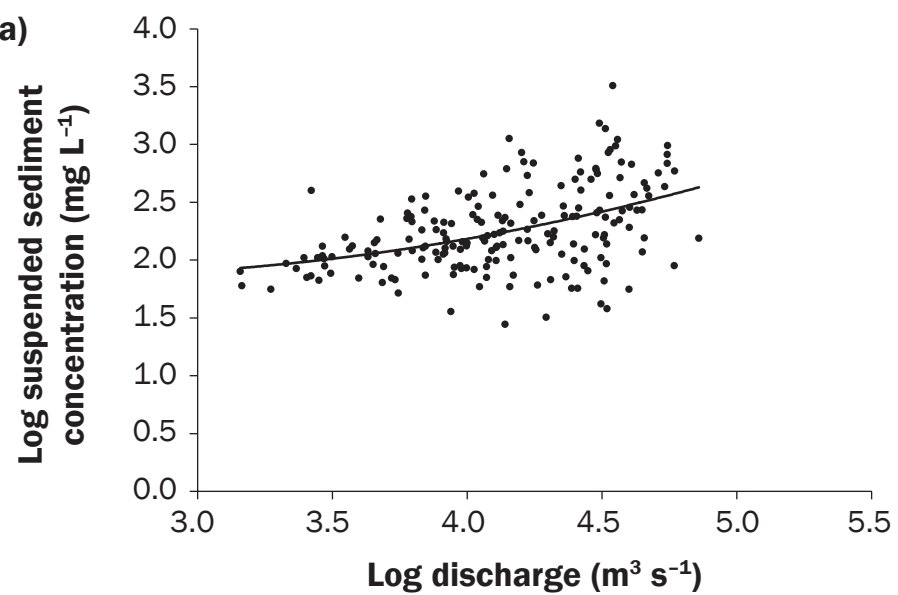

(b)

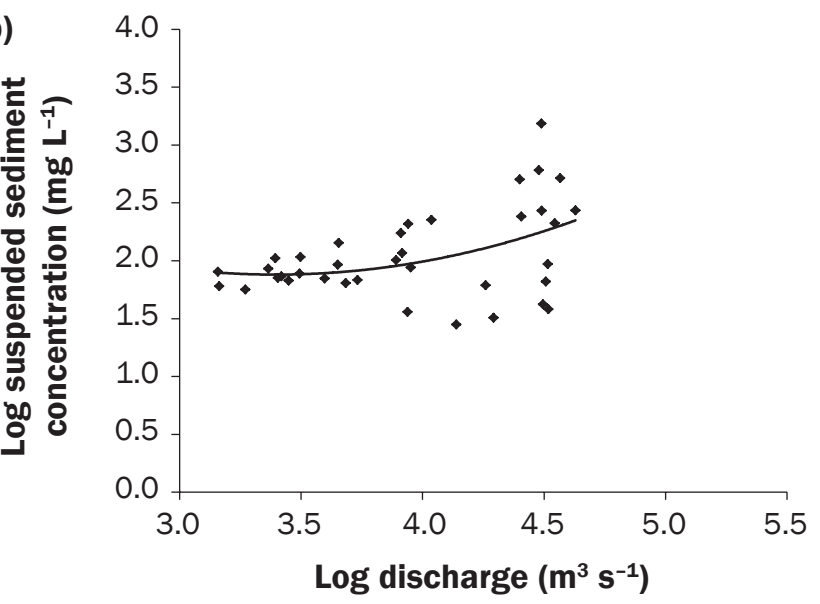

and 2008, precipitation was above average for Iowa, particularly in June of 2008 when the IRB experienced one of the largest floods in recent history. In fact, the 16-day flood in June of 2008 transported more than $9 \%$ of the cumulative yearly sediment load (Hubbard et al. 2011), which likely consisted of a large percentage of bed sediment now unavailable for transport within the basin.

The sediment rating curve shape (2007 to 2008; figure 4) for Yazoo-4 was slightly concave, suggesting an almost unlimited sediment supply. Channel downcutting in the basin is supplying sediment to the streams, and sediment transport within the basin is driven by discharge.

Specific Sediment Yield at Differing Watershed Sizes. The "scale effect," meaning that SSY measured at one scale is not representative of the SSY at another scale, has been well documented by several authors (Menard 1961; Judson and Ritter 1964; Holeman 1968; Walling 1984; Meade and Parker 1985; Waythomas and Williams 1988; Walling and Webb 1996; Osterkamp and Toy 1997; Dedkov 2004; de Vente and Poesen 2005; Jiongxin and Yunxia 2005; Lu et al. 2005; de Vente et al. 2007). In the YRB, the SSY decreased from the smallest to the largest scales (table 3). In the IRB, however, the SSY scale effect is different. From the $2 \mathrm{~km}^{2}(0.8$ $\mathrm{mi}^{2}$ ) scale, SSY increased but then remained constant to the $500 \mathrm{~km}^{2}\left(193 \mathrm{mi}^{2}\right)$ scale. A decrease in SSY occurred as watershed area increased beyond $500 \mathrm{~km}^{2}$ (table 3). At small to intermediate watershed scales, much of the stream network in the IRB is formed mainly by ditches - straight open drainage channels characterized by flat bed slopes, low stream velocities, and steeper bank slopes. Many of these ditches were installed during the early 20th century, drastically altering natural drainage patterns by connecting subsurface drainage to channels in lower parts of the watershed. The increased volumes of flow discharged from drainage ditches has contributed to bank instability in the lower parts of the watershed and has encouraged migration of meanders, as observed in the SFIR (Simon and Klimetz 2008). In addition, sedimentation has increased bank heights of streams by approximately $1 \mathrm{~m} \mathrm{(3.3}$ $\mathrm{ft})$ relative to presettlement conditions (Yan et al. 2010) resulting in an increase in bank- 
Table 5

Specific sediment yields and soil management practices for agricultural fields in the lowa River and Yazoo River basins reported in previous studies.

\begin{tabular}{|c|c|c|c|c|}
\hline Basin area $\left(\mathrm{km}^{2}\right)$ & Study years & $\begin{array}{l}\text { Specific } \\
\text { sediment yield } \\
\left(\mathrm{Mg} \mathrm{km}^{-2} \mathrm{y}^{-1}\right)\end{array}$ & Soil management & Reference \\
\hline \multicolumn{5}{|l|}{ lowa River basin } \\
\hline 0.06 & Simulated 50 years & 93 & Chisel-plow tillage + BMP (CP + BMP); corn-soybeans & Zhou et al. (2009) \\
\hline 0.06 & Simulated 50 years & 74 & Strip-tillage + BMP (ST + BMP); corn-soybeans & Zhou et al. (2009) \\
\hline 0.06 & Simulated 50 years & 47 & No-tillage + BMP (NT + BMP) & Zhou et al. (2009) \\
\hline 0.10 & 1997 to 1999 & 1,125 & Conventional tillage soybeans (CT), cotton, and wheat & Rebich and Knight (2001) \\
\hline 0.10 & 1997 to 1999 & 375 & $\begin{array}{l}\text { Conservation tillage soybeans (CONS), cotton, } \\
\text { and wheat }\end{array}$ & Rebich and Knight (2001) \\
\hline 0.12 & Simulated & 1,001 & Conventional tillage (S-CT) cotton and soybeans & Yuan et al. (2002) \\
\hline 0.12 & Simulated & 479 & $\begin{array}{l}\text { Reduced tillage + BMP (S-RT + BMP), cotton } \\
\text { and soybeans }\end{array}$ & Yuan et al. (2002) \\
\hline
\end{tabular}

\section{Figure 5}

Relation between log specific sediment yield (SSY [average SSY measured]) and log basin area for (a) lowa River basin (IRB) and (b) Yazoo River basin (YRB) using different soil management practices (CP = chisel-plow tillage, $\mathrm{BMP}=$ best management practice, $\mathrm{NT}=$ no-tillage, $\mathrm{ST}=$ strip-tillage, $\mathrm{CT}=$ conventional tillage, CONS = conservation tillage, $S=$ cotton and soybeans, and $\mathrm{RT}=$ reduced tillage).

(a)

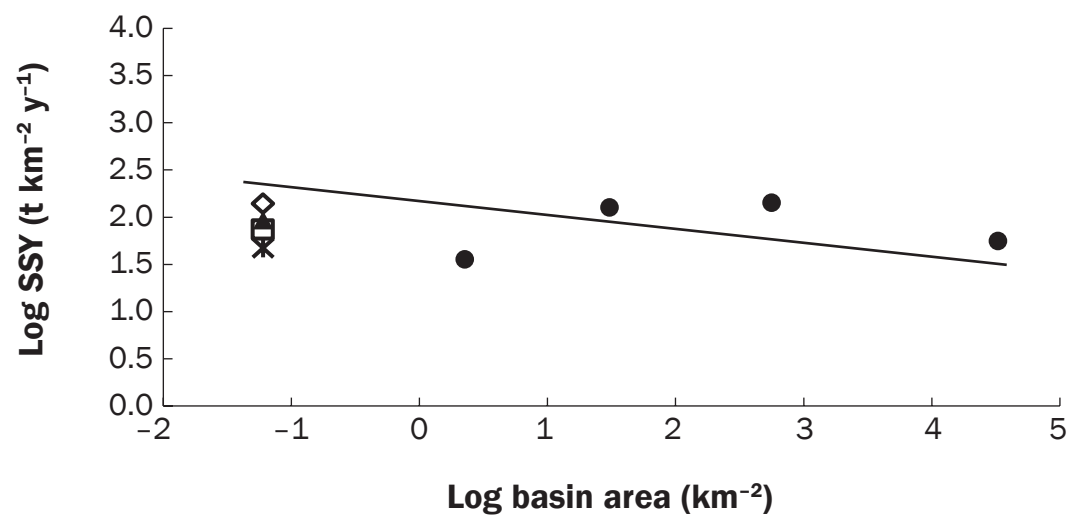

\section{Legend}

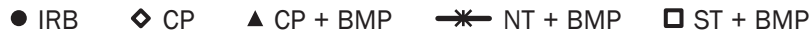

(b)

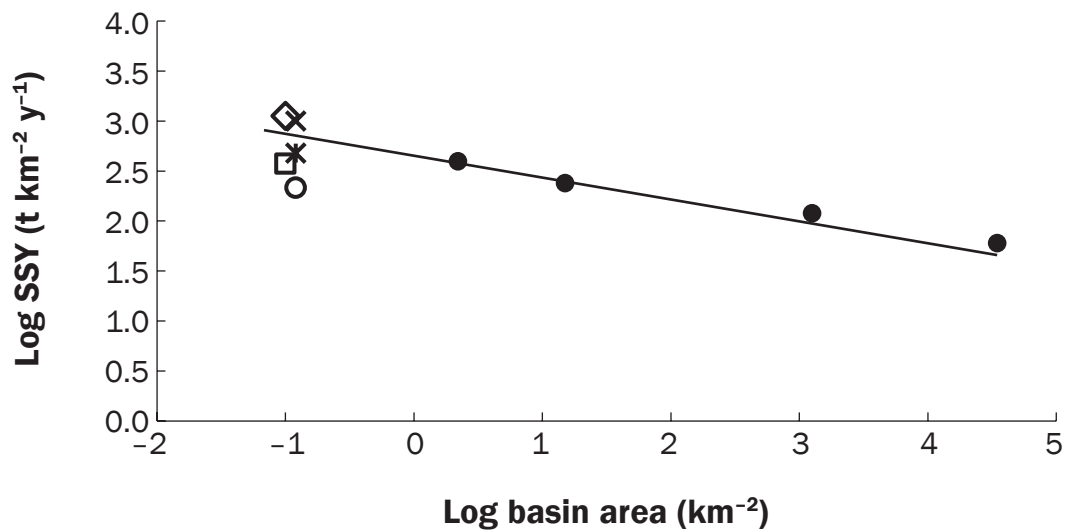

Legend

- YRB $\diamond \mathrm{CT} \quad \mathrm{CCONS}$ * $\mathrm{S}-\mathrm{RT}+\mathrm{BMP} \quad \boldsymbol{-} \mathrm{S}-\mathrm{NT}+\mathrm{BMP} \times \mathrm{S}-\mathrm{CT}$ full area and greater erosion of the channel. Wilson et al. (2008) and Tomer et al. (2010) used two tracers, beryllium-7 ( $\left.{ }^{7} \mathrm{Be}\right)$ and lead$210\left({ }^{210} \mathrm{~Pb}_{\mathrm{xs}}\right)$, to identify the contributors to sediment loads in the IRB at a $198 \mathrm{~km}^{2}(76$ $\mathrm{mi}^{2}$ ) area site during a September of 2006 runoff event. Results showed that $80 \%$ of the sediment load was composed of sediments from channel erosion and $20 \%$ was from sheet and rill erosion.

Land Management Effects. The effectiveness of soil management practices used by farmers on agricultural lands to reduce the SSY at Iowa-1 and Yazoo-1 watersheds can be evaluated by comparing our study results with results from previously published experimental results for watersheds similar in size to Iowa-1 and Yazoo-1. Previous study results, summarized in table 5, are a compilation of field-scale SSY measured and/ or model-simulated values in which soils were managed with and without conservation practices. These results are combined with our study results in figure 5 . Iowa-1 has the lowest SSY from any basin scale, which could be associated with sediment settling in depressions, roadside ditches, and other depositional features before reaching the stream. The log-linear trend in both the IRB and YRB is consistent with field-scale erosion rates associated with older "conventional" tillage systems, as identified through modeling and field studies (table 5). This trend indicates that the log-linear SSY relations in the IRB and YRB watersheds may still be influenced by past agricultural land-use practices prior to the modern conservation tillage practices that became dominant during the 1980s. The parabolic log-linear SSY basin trend observed in the measured SSY data 
from the IRB suggests that the conservation soil management and the drainage practices utilized in Iowa- 1 have become effective in lowering the sediment losses, at least in small upper basins. In addition, the maximum sediment load occurs for a channel that is known to be actively widening (Simon and Klimetz 2008), with sediment loads that are increased by accreted historical sedimentation (Yan et al. 2010). The combination of conservation success in small basins and active geomorphic processes occurring along channels draining intermediate basin sizes probably explains the parabolic shape of the curve for the IRB. On the other hand, at Yazoo-1, the SSY measured value from our study is aligned with the SSY log linear trend value, suggesting that the soil management employed to reduce soil erosion in this watershed has not been effective in lowering the SSY losses at small basin scales. There are much greater challenges to control SSY in the YRB, due not only to greater rainfall erosivity and finer-textured soils, but also to stream downcutting, which has led to active expansion of gullies, particularly in upper reaches of this basin (Wilson et al. 2008). The smaller streams we monitored in the IRB are little affected by downcutting due to the presence of coarse glacial outwash, which restricts stream incision (Yan et al. 2010), but this does not apply to headwater basins throughout the larger IRB. Despite these differences, in both basins, we have shown evidence that SSY-scaling relationships remain impacted by large rates of agricultural erosion that occurred many years ago.

\section{Summary and Conclusions}

Data from 1996 to 2008 show that, on average, the YRB delivers 1.6 times more water by volume and yields 2.5 times more suspended sediment than the IRB. This difference is driven by factors including higher rain erosivity and greater overland flow fractions associated with finer-textured soils in the YRB than in the IRB, along with fluvial and geomorphologic differences. YRB fluvial channels are more susceptible to downcutting than channels in the IRB, which can lead to gully expansion in upper smaller tributaries.

Despite predominantly dry weather conditions in Mississippi during 2007 and 2008 and unusually wet conditions in Iowa for the same period, SSY from the smallest watersheds was higher in the YRB than the IRB
( 2 $\mathrm{km}^{2}$ [1.24 mi]). With increasing drainage basin area, the relation between suspended sediment yield and drainage basin size differed between the sites in the YRB and sites in the IRB due to differences in field drainage practices, soil type, geomorphology, and fluvial processes within each basin. In the YRB, SSY decreased as basin area increased, whereas the SSY drainage basin area relation in the IRB had a nonlinear trend. The IRB SSY was lowest in the smallest watersheds because discharge at the site was derived from overland flow and tile drains low in sediment, and dominant erosion processes in the IRB occur within the fluvial channel of the intermediate-sized streams. The results of this study, in conjunction with previous published studies of small watersheds $\left(\sim 2 \mathrm{~km}^{2}\right)$, suggest that soil management practices are reducing SSY to a greater degree from the fields of the IRB compared to the YRB. Yet, in both basins, we showed evidence that the SSY-basin scale relationships are still affected by historical rates of erosion that occurred prior to implementation of conservation practices.

\section{Acknowledgements}

The authors thank their colleagues in the US Geological Survey (USGS) who contributed time, effort, and expertise toward study design, implementation, and sampling. The authors would also like to extend deep gratitude to the landowners who allowed access to their land. Thoughtful reviews by Arthur J. Horowitz (research chemist with the USGS in Atlanta, Georgia), Gary Johnson (chief of the hydrologic data section, USGS, Urbana, Illinois), Richard Coupe (retired hydrologist for the USGS), Paul Capel (hydrologist and research team leader with the USGS in Minneapolis, Minnesota), and Martin Locke (leader of the water quality and ecology research unit in the National Sedimentation Laboratory for the USDA ARS in Oxford, Mississippi) improved this paper. The work by Gustavo H. Merten was done while serving as a Volunteer for Science with the USGS.

\section{References}

Asselman, N.E.M. 2000. Fitting and interpretation of sediment rating curves. Journal of Hydrology 234: 238-248.

Coupe, R.H. 2002. Nitrogen and phosphorus concentrations and fluxes of streams in the Mississippi Embayment study unit. US Geological Survey (USGS) Water-Resources Investigations Report 01-4024.

Coupe, R.H., and P.D. Capel. 2005. Bogue Phalia watershed in Mississippi selected for national waterquality study. USGS Fact Sheet 2005-3050.

Church, M., and H.O. Slaymaker. 1989. Disequilibrium of Holocene sediment yield in glaciated British Columbia. Nature 337:452-454. de Vente, J., and J. Poesen. 2005. Predicting soil erosion and sediment yield at the basin scale: Scale issues and semiquantitative models. Earth-Science Reviews 71:95-125.

de Vente, J., J. Poesen, M. Arabkhedri, and G. Verstraeten. 2007. The sediment delivery problem revisited. Progress in Physical Geography 31:155-178.

Dedkov, A. 2004. The relationship between sediment yield and drainage basin area. In Sediment Transfer through the Fluvial System, pp. 197-204. Publication 288. Wallingford, UK: International Association of Hydrological Sciences.

Delaune, R.D., W.H. Patrick, Jr., and C.J. Smith. 1992. Marsh aggradation and sediment distribution along rapidly submerging Louisiana Gulf Coast. Environmental Geology 20(1):57-64.

Dendy, F.E. 1981. Sediment yield from a Mississippi Delta cotton field. Journal of Environmental Quality 10:482-486.

Dos Reis Castro, N.M., N.M. Auzet, P. Chevallier, and J.C. Leprun. 1999. Land use change effects on runoff and erosion from plot to catchment scale on the basaltic plateau of Southern Brazil. Hydrological Processes 13:1621-1628.

Duan, N. 1983. Smearing estimate: A nonparametric retransformation method. Journal of the American Statistical Association 78:605-610.

Duriancik, L.F., D. Bucks, J.P. Dobrowolski, T. Drewes, S.D. Eckles, L. Jolley, R.L. Kellogg, D. Lund, J.R. Makuch, M.P. O'Neill, C.A. Rewa, M.R. Walbridge, R. Parry, and M.A. Weltz. 2008. The first five years of the Conservation Effects Assessment Project. Journal of Soil and Water Conservation 63(6):185-197, doi:10.2489/ jswc.63.6.185A.

Edwards, T.K., and G.D. Glysson. 1999. Field methods for measurement of fluvial sediment. In Techniques of WaterResources Investigations of the US Geological Survey, Book 3, Chapter C2. Denver: US Geological Survey.

Guy, H.P. 1969. Laboratory theory and methods for sediment analysis. In Techniques of Water-Resources Investigations of the US Geological Survey, Book 5, Chapter C1. Denver: US Geological Survey.

Holeman, J.N. 1968. The sediment yield of major rivers of the world. Water Resources Research 4:737-747.

Horowitz, A.J. 2003. An evaluation of sediment rating curves for estimating suspended sediment concentrations for subsequent flux calculations. Hydrological Processes 17:3387-3409.

Horowitz, A.J. 2008. Monitoring urban impacts on suspended sediment, trace element, and nutrient fluxes within the City of Atlanta, Georgia, USA: Program design, methodological considerations, and initial results. Hydrological Processes 22:1473-1496.

Horowitz, A.J. 2010. A quarter century of declining suspended sediment fluxes in the Mississippi River and the effect of the 1993 flood. Hydrological Processes 24:13-34 
Horowitz, A.J, K.A. Elrick, and J.J. Smith. 2001. Estimating suspended sediment and trace element fluxes in large river basins: Methodological considerations as applied to the NASQAN programme. Hydrological Process 15:1107-1132.

Hubbard, L., D.W. Kolpin, S.J. Kalkhoff, and D.M Robertson. 2011. Nutrient and sediment concentrations and corresponding loads during the historic June 2008 flooding in eastern Iowa. Journal of Environmental Quality 40:166-175.

Jiongxin, X., and Y. Yunxia. 2005. Scale effects on specific sediment yield in the Yellow River basin and geomorphological explanations. Journal of Hydrology 307: 219-232.

Judson, S., and D.F. Ritter. 1964. Rates of regional denudation in the United States. Journal of Geophysical Research 69:3395-3401.

Kalkhoff, S.J., K.K. Barnes, K.D. Becher, M.E. Savoca, D.J. Schnoebelen, E.M. Sadorf, S.D. Porter, and S.J Sullivan. 2000. Water quality in the Eastern Iowa Basins, Iowa and Minnesota, Circular 1210, 1996-98. Denver: USGS, US Department of the Interior.

Kalkhoff, S.J., and P.D. Capel. 2005. South Fork Iowa River watershed selected for national water-quality study. US Geological Survey Fact Sheet 2005-3064.

Karlen, D.L., M.D. Tomer, J. Neppel, and C.A Cambardella. 2008. A preliminary watershed scale soil quality assessment in north central Iowa. Soil \& Tillage Research 99:291-299.

Knight, S.S., M.A. Locke, and S. Smith. 2013. Effects of agricultural conservation practices on oxbow lake watersheds in the Mississippi River Alluvial Plain. Soil and Water Research 8:113-123.

Leys, A., G. Govers, K. Gillijns, E. Berckmoes, and I. Takken. 2010. Scale effects on runoff and erosion losses from arable land under conservation and conventional tillage: The role of residue cover. Journal of Hydrology 390:143-154

Linhart S.M., and D.A. Eash. 2010. Floods of May 30 to June 15, 2008, in the Iowa River and Cedar River basins, eastern Iowa. US Geological Survey Open-File Report 2010-1190, $32 \mathrm{p}$

Locke, M.A., S.S. Knight, S. Smith Jr., R.F. Cullum, R.M. Zablotawicz, Y. Yuan, and R.L. Bingner. 2008 Environmental quality research in the Beasley Lake watershed, 1995 to 2007: Succession from conventional to conservation practices. Journal of Soil and Water Conservation 63:430-442, doi:10.2489/jswc.63.6.430.

Lu, H., C.J. Moran, and M. Sivapalan. 2005. A theoretical exploration of catchment-scale sediment delivery. Water Resources Research 41 W09415.

Meade, R.H., and J.A. Moody. 2010. Causes for the decline of suspended-sediment discharge in the Mississippi River system, 1940-2007. Hydrological Processes 24:35-49.

Meade, R.H., and R.S. Parker. 1985. Sediment in rivers of the United States in National Water Summary 1984; hydrologic events, selected water-quality trends, and ground-water resources. US Geological Survey Water Supply Paper 2275.

Menard, H.W. 1961. Some rates of regional erosion. Journal of Geology 69:154-161.

Minella, J.G., D.E. Walling, and G.H. Merten. 2014 Establishing a sediment budget for small agricultural catchment in southern Brazil to support the development of effective sediment management strategies. Journal of Hydrology 519:2189-2201.

MSU Extension Service (Mississippi State University Delta Research and Extension Center-Weather). 2006. Bart Freeland WWW Papers. http://ext.msstate.edu/anr/drec/.

Murphree, C.E., C.K. Mutchler, and K.C. McGregor 1985. Sediment yield from a 259-ha flatlands watershed. Transactions of the American Society of Agricultural and Biological Engineers 28:1120-1123.

NOAA (National Oceanic and Atmospheric Administration). 2013. http://www.ncdc.noaa.gov/cdo-web/.

Osterkamp, W.R., and T.J. Toy. 1997. Geomorphic considerations for erosion prediction. Environmental Geology 29(3/4):152-157.

Pettry, D.E. 1977. Soil Resource Areas of Mississippi. Information sheet no. 1278. Mississippi Agricultural and Forestry Experiment Station, Mississippi State University. Starkville, MS: Mississippi State University.

Porterfield, G. 1977. Computation of fluvial-sediment discharge. In Techniques of Water-resources Investigations of the US Geological Survey, Chapter C3, Book 3. Washington, DC: US Geological Survey.

Rantz, S.E. 1982. Measurement and Computation of Streamflow: Volume 1. Measurement of Stage and Discharge and Volume 2. Computation of Discharge. USGS Water Supply Paper 2175. Washington, DC: US Government Printing Office.

Rebich, R., and S. Knight. 2001. The Mississippi Delta Management Systems Evaluation Area Project, 1995-99. Mississippi Agricultural and Forestry Experiment Station Information Bulletin 377, Division of Agriculture, Forestry andVeterinary. Starkville, MS: Mississippi State University.

Renard, K.G., G.R. Foster, G.A. Weesies, D.K. McCool, and D.C. Yoder. 1997. Predicting soil erosion by water-A guide to conservation planning with the Revised Universal Soil Loss Equation (RUSLE). USDA Agricultural Handbook 703. Washington DC: US Government Printing Office.

Renwick, W.H, and Z.D. Andereck. 2006. Reservoir Sedimentation Trends in Ohio, USA: Sediment Delivery and Response to Land Use Change. In Sediment Dynamics and the Hydromorphology of Fluvial Systems, eds. J.S. Rowen, R.W. Duck, and W.S. Wallingford, UK: International Association of Hydrological Sciences (IAHS)

Renwick, W.H., and M.T. Rakovan. 2010. Sediment supply limitation and stream restoration. Journal of Soil and Water Conservation 65(3):67, doi:10.2489/ jswc.65.3.67A.

Renwick, W.H., S.U. Smith, J.D. Bartley, and R.W. Buddenmeier. 2005. The role of impoundments in the sediment budged of the conterminous United States. Geomorphology 71:99-111.

Roehl, J.W. 1962. Sediment source areas, delivery ratios and influencing morphological factors. Publication 59, International Association of Scientific Hydrology, Commission of Land Erosion.

Shaw, D.R., S.M. Schraer, J. Prince, and M. Boyette. 2006. Herbicide dynamics in the Bogue Phalia watershed in the Yazoo River basin of Mississippi. Weed Science 54:807-813.

Sichingabula, H.M. 1998. Factors controlling variations in suspended sediment concentration for single-valued sediment rating curves, Fraser River, British Columbia, Canada. Hydrological Processes 12:1869-1894.

Simon, A., and L. Klimetz. 2008. Relative magnitudes and sources of sediment in benchmark watersheds of the Conservation Effects Assessment Project. Journal of Soil and Water Conservation 63:504-522, doi:10.2489/ jswc.63.6.504.

Soil Survey Staff. 1999. Soil taxonomy: A basic system of soil classification for making and interpreting soil surveys. 2nd edition. US Department of Agriculture Handbook 436. Washington, DC: USDA NRCS (Natural Resources Conservation Service). http://www.nrcs.usda.gov/wps/ portal/nrcs/main/soils/survey/class/taxonomy/.

Tomer, M.D, and M.A. Locke. 2011. The challenge of documenting water quality benefits of conservation practices: A review of USDA ARS's conservation effects assessment project watershed studies. Water Science and Technology 64(1):300-310.

Tomer, M.D.,T.B. Moorman, D.E.James, G. Hadish, and C.G. Rossi. 2008. Assessment of the Iowa River's South Fork watershed: Part 2. Conservation Practices. Journal of Soil and Water Conservation 63(6):371-379, doi:10.2489/ jswc.63.6.371.

Tomer, M.D., C.G.Wilson, T.B. Moorman, K.J. Cole, D. Herr, and T.M. Isenhart. 2010. Source-pathway separation of multiple contaminants during a rainfall-runoff event in an artificially drained agricultural watershed. Journal of Environmental Quality 39:882-895

Trimble, S.W. 1999. Decreased rates of alluvian sediment storage in Coon Creek basin, Wisconsin, 1975-90. Science 285:1244-1246.

Turner, R.E., M.N. Rabelais, R.B. Alexander, G. McIsaac, and R.W. Howarth. 2007. Characterization of nutrient, organic carbon and sediment loads and concentrations from the Mississippi River into the northern Gulf of Mexico. Estuaries and Coast 30:773-790.

USDA. 2010. Assessment of the Effects of Conservation Practices on Cultivated Cropland in the Upper Mississippi River Basin. Conservationist Effects Assessment Project (CEAP). http://www.nrcs.usda.gov/ technical/nri/ceap.

USDA. 2013. Assessment of the Effects of Conservation Practices on Cultivated Cropland in the Lower Mississippi River Basin. CEAP. http://www.nrcs.usda. gov/technical/nri/ceap. 
USDA NRCS. 2010. 2007 National Resource Inventory. 2007 Annual NRI- Soil Erosion.

USGS (US Geological Survey). 2014. USGS Water Data for the Nation. http://waterdata.usgs.gov/nwis.

van Noordwijk, M., M. van Roode, M. McCallie, and B. Lusiana. 1998. Erosion and sedimentation as multi-scale, fractal processes: Implications for models, experiment and the real world. In Soil erosion at multiple scales: Principle and methods for assessing causes and impact, eds. Penning de Vries FWT, Agus F, and Kerr J, pp. 223-253. Wallingford, UK: CAB International.

Vanoni, V.A. 1975. Nature of sedimentation problems. In Sedimentation Engineering, ASCE Task Committee for the Preparation of the Manual on Sedimentation of the Sedimentation Committee of the Hydraulics Division, pp. 1-16. New York: American Society of Civil Engineers.

Walling, D.E. 1983. The sediment delivery problem. Journal of Hydrology 65:209-237.

Walling, D.E. 1984. The sediment yields of Africa. In Challenges in African Hydrology and Water Resources, Proceedings of the Harare Symposium, July 1984, no. 144, pp. 265-283. Wallingford, UK: International Association of Hydrological Sciences.

Walling, D.E. 1999. Linking land use, erosion and sediment yields in river basins. Hydrobiologia 410:223-240.

Walling, D.E. 2008. The changing sediment loads of the world's rivers. Land Reclamation 39:3-20.

Walling, D.E., and B.W. Webb. 1996. Erosion and sediment yield: A global overview. In Erosion and Sediment Yield: Global and Regional Perspectives, no. 236, pp. 3-19. Wallingford, UK: International Association of Hydrological Sciences.

Waythomas, C.F., and G.P. Williams. 1988. Sediment yield and spurious correlation-toward a better portrayal of the annual suspended-sediment load of rivers. Geomorphology 1:309-316.

Williams, J.R., and H.D. Berndt. 1977. Sediment yield prediction based on watershed hydrology. Transactions of the American Society of Agricultural Engineers 20(6):1100-1104.
Wilson, C.G, R.A. Kuhnle, D.D. Bosch, J.L. Steiner, P.J. Starks, M.D.Tomer, and G.V.Wilson. 2008. Quantifying relative contributions from sediment sources in Conservation Effects Assessment Project watersheds. Journal of Soil and Water Conservation 63(6):523-532, doi:10.2489/ jswc.63.6.523.

Wilson, G.V., F.D. Shields Jr, R.L. Bingner, P. ReidRhoades, D.A. DiCarlo, and S.M. Dabney. 2008. Conservation practices and gully erosion contributions in the Topashaw Canal watershed. Journal of Soil and Water Conservation 63(6):420-429, doi:10.2489/ jswc.63.6.420.

Wischmeier, W.H., and D.D. Smith. 1978. Predicting Rainfall Erosion Losses - A Guide to Conservation Planning. USDA Handbook 537. Washington, DC: USDA-Science and Education Administration.

Wood, P.L., and P.D. Armitage. 1997. Biological effects of fine sediment in the lotic environment. Environmental Management 21:203-217.

Yan, B., M.D. Tomer, and D.E. Jones. 2010. Historical channel movement and sediment accreation along the South Fork of Iowa River. Journal of Soil and Water Conservation 65(1):1-8, doi:10.2489/jswc.65.1.1.

Yuan, Y., and R.L. Bingner. 2002. Assessment of best management practices for water quality improvement for the Deep Hollow watershed in Mississippi delta MSEA project using AGNPS. Research Report 28 Oxford, MS: National Sedimentaiton Laboratory, USDA Agricultural Research Service. www.ars.usda.gov/ SP2UserFiles/Place/6408/0510/TechnicalReports/ NSLTechnicalReport28.pdf.

Yuan, Y., M.A. Locke, and R.L. Bingner. 2008 Annualized Agricultural Non-Point Source model application for Mississippi Delta Beasley Lake watershed conservation practices assessment. Journal of Soil and Water Conservation 63(6):542-551, doi:10.2489/ jswc.63.6.542.

Zhou, X., M. Al-Kaisi, and M.J. Helmers. 2009. Cost effectiveness of conservation practices in controlling water erosion in Iowa. Soil Tillage Research 106:71-78. 